\title{
Original article \\ Static postural balance in healthy individuals: Comparisons between three age groups
}

\author{
Yanne Salviano Pereira \\ Jéssica Mascena de Medeiros \\ Federal University of Paraiba at João Pessoa, Brazil \\ José Ângelo Barela \\ Ana Maria Forti Barela \\ Cruzeiro do Sul University at São Paulo, Brazil \\ César Ferreira Amorim \\ University of the City of São Paulo, Brazil \\ Catarina de Oliveira Sousa \\ Federal University of São Carlos, Brazil \\ Palloma Rodrigues de Andrade \\ José Jamacy de Almeida Ferreira \\ Heleodório Honorato dos Santos \\ Federal University of Paraíba at João Pessoa, Brazil
}

\begin{abstract}
The aim of the study was to compare static postural balance of healthy individuals of three age groups in different conditions of support and vision. Seventy one individuals, divided into 3 groups, were analyzed: young group (YG: 22.2 \pm 2.1 years), middle aged group (MAG: $50.7 \pm 5.7$ years) and older individuals group (EG: $66.8 \pm 5.4$ years). Their balance was tested on a force platform, under 3 support and 3 visual conditions. Measures included: total (TD), anterior-posterior (APD) and mediolateral displacement (MLD) of the center of pressure (CoP). ANOVA revealed significant differences for interactions between group X support conditions and group X visual conditions for the 3 variables $(p<0.01)$, with greater displacements for the MAG and EG groups during single-leg stance with partial and occluded vision $(p<0.05)$. Static postural balance decreased over time in healthy individuals, and conditions of support and visual negatively affected balance with the increment of age.
\end{abstract}

Keywords: age groups, sensory feedback, posture

Resumo - “Equilíbrio postural estático em indivíduos saudáveis: Comparações entre três grupos etários." O objetivo do estudo foi comparar o equilíbrio postural estático de indivíduos saudáveis de três faixas etárias em diferentes condições de apoio e de visão. Foram analisados 71 sujeitos, divididos em 3 grupos: jovens (GJ: 22,2 22,1 anos); meia idade (GMI: 50,7 $\pm 5,7$ anos) e idosos (GI: 66,8 $\pm 5,4$ anos). O equilíbrio foi testado numa plataforma de força, em 3 condições de apoio e 3 condições de visão, avaliando-se o deslocamento total (DT), ântero-posterior (DAP) e médio-lateral (DML) do centro de pressão $(\mathrm{CP})$. ANOVA mostrou interação grupo X condições de apoio e grupo X condições visuais, nas 3 variáveis estudadas $(p<0,01)$, com maiores deslocamentos no GMI e GI no apoio unipodal com visão parcial e ausente $(p<0,05)$. O equilíbrio postural estático em indivíduos saudáveis diminuiu ao longo do tempo e que as condições de apoio e de visão podem afetá-lo negativamente com o avançar da idade.

Palavras-chave: grupos etários, retroalimentação sensorial, postura

Resumen - “Equilibrio postural estático en individuos sanos: Las comparaciones entre los tres grupos de edad.” El objetivo del estudio fue comparar el equilibrio postural estático de individuos sanos de tres grupos de edad em diferentes condiciones de apoyo y visón. Fueran analizados 71 sujetos, divididos en 3 grupos: jóvenes (GJ: 22,2士2,1 años), de mediana edad (GME: 50,7 $\pm 5,7$ años) y ancianos (GA: 66,8 $\pm 5,4$ años). El equilibrio fue probado en una plataforma de fuerza, em 3 condiciones de apoyo y 3 condiciones de visión, evaluando el desplazamiento total (DT), anteroposterior (DAP) y mediolateral (DML) del centro de presión (CP). ANOVA mostró interacción grupo X condiciones de apoyo y 
grupo X condiciones visuales, en las 3 variables $(p<0,01)$, con grandes desplazamientos en GME y GA en apoyo unipodal con visión parcial y ausente $(p<0,05)$. El equilibrio postural estático disminuyó en individuos sanos con el tiempo y que las condiciones de apoyo y de visión pueden afectarle negativamente con la edad.

Palabras clave: grupos de edad, retroalimentación sensorial, postura

\section{Introduction}

Brazil has a rapidly aging population, target to significant changes Data from the Brazilian Institute of Geography and Statistics (Instituto Brasileiro de Geografia e Estatística, IBGE) in 2010 has indicated that the Brazilian population over 60 years of age was fastest growing group in the last decade, increasing approximately $8 \%$ of the total population ( 14.5 million people) to approximately $10.8 \%$ (20 million). According to statistical projections of the World Health Organization, in the period from 1950 to 2025, the group of older people in Brazil is expected to increase approximately fifteen times, reaching, in 2025, about 32 million people aged 60 and older (Instituto Brasileiro de Geografia e Estatística, 2000, 2010).

According to Kirkwood (2002), aging is a process that begins at conception and continues throughout the lifespan. Aging causes physiological changes with various effects. Many of the physiological changes attributed to aging occur in a progressive manner and compromise independence and functional status of older individuals, leading, for example, to decreased strength and proprioception, (Alfieri \& Moraes, 2008), deficits of sensory systems (Nardone \& Schieppati, 2010; Ricci, Gazzola, \& Coimbra, 2009) and changes in gait and balance (Abreu \& Caldas, 2008).

Among the most prominent physiological changes caused by aging is the decreased balance and its important functional limitations (Nascimento, Patrizzi, \& Oliveira, 2012). Freitas Junior and Barela (2006) observed that deficit of balance is one of the main cause of high rate of falls among older individuals, mainly due to the decreased ability of sensory (visual, somatosensory and vestibular) and motor systems to keep the body oriented.

The maintenance of stability is a dynamic process that involves adjustments between stabilization and destabilization forces. Here, the control strategies are dependent on interactions between the individual, the task at hand, and the environment. Such strategies are triggered by accurate and specific sensory input, and are influenced by the integrity of motor process (Duarte \& Zatsiorsky, 2002). Posture and balance involve, both, the ability to recover from instability, and the ability to anticipate and move in order to avoid instability (Leonardi, Lopes, Bezerra, \& Borges, 2009).

Several studies have examined the effects of institutionalization (Aikawa, Braccialli, \& Padula, 2006; Alves \& Scheicher, 2011), disease (Gazzola, Perracini, Ganança, \& Ganança, 2006), and regular physical activity (Bruni, Granado, \& Prado, 2008) on static balance in older individuals. However, few studies have reported how aging affects stability over time in this age group.

Some recent studies have shown the effects of strength and multisensory training under different conditions of support and visual restrictions (Alfieri et al., 2010; 2012), and the impact of standing on one foot - regardless dominance of members - (Gil et al., 2011; Maciel \& Guerra, 2005) on the displacement of the center of pressure. However, the literature is sparse in analyzing balance in response to sensory factors such as different types of support and types of visual restriction in different age groups.

Studying the effects of sensory stimuli associated with three age groups is important because it attempts to identify stimuli that are more related to balance changes as age advances. From this perspective, the aim of this study was to compare static postural balance of healthy individuals of the three age groups in different conditions of support and vision.

\section{Methods}

\section{Study design and sample}

This work consisted in a cross-sectional and descriptive study conducted at the Laboratory of Biological Signal Processing in the Core Studies of Human Movement at Federal University of Paraíba (CSHM/UFPB).

The study was approved by the Research Ethics Committee Lauro Wanderley University Hospital (CEP/HULW/UFPB), under the protocol number 009/2009. Individuals were informed about the study's purpose, and signed a consent form, agreeing to participate in the study, according to the Brazilian National Health Council (NHC), Resolution 196/96.

The sample was selected by convenience, meeting the following inclusion criteria: age between 20 and 80 years old, and based on a physiotherapy evaluation form, no disorders that would compromised static balance were identified, such as: chronic vestibular syndrome, labyrinthitis, vertigo and/or neurological, cognitive and/or orthopedic impairments.

The study included 71 volunteers, male and female, divided into 3 groups (Figure 1) according to age: 1 - the youth group (YG $=25$ individuals: 14 men and 11 women, $22.2 \pm 2.1$ ), ages between 20 and 40 years; 2 - the middle-aged group (MAG $=23$ individuals: 10 men and 13 women; $50.7 \pm 5.7$ years), ages between 41 and 60 , and 3 - the group of older individuals $(E G=23$ individuals: 9 men and 14 women, $66.7 \pm 5.4$ years), ages over 60 years, who regularly participated in an exercise program that includes, for example, water gymnastics, lasting 1 hour twice a week.

The sample size was estimated by means of a pilot study that determined the necessary number of participants for each group (www.lee.dante.br). The criterion was to meet a difference of 1.3 $\mathrm{cm}$ of anterior-posterior postural displacement (APD). A total of 21 individuals would be needed for each group, considering a significance level of $5 \%$, power of test of $80 \%$, and a standard deviation of $1.5 \mathrm{~cm}$. To prevent possible dropouts, we added at least two subjects in each group, resulting in a total sample of 71 subjects. 


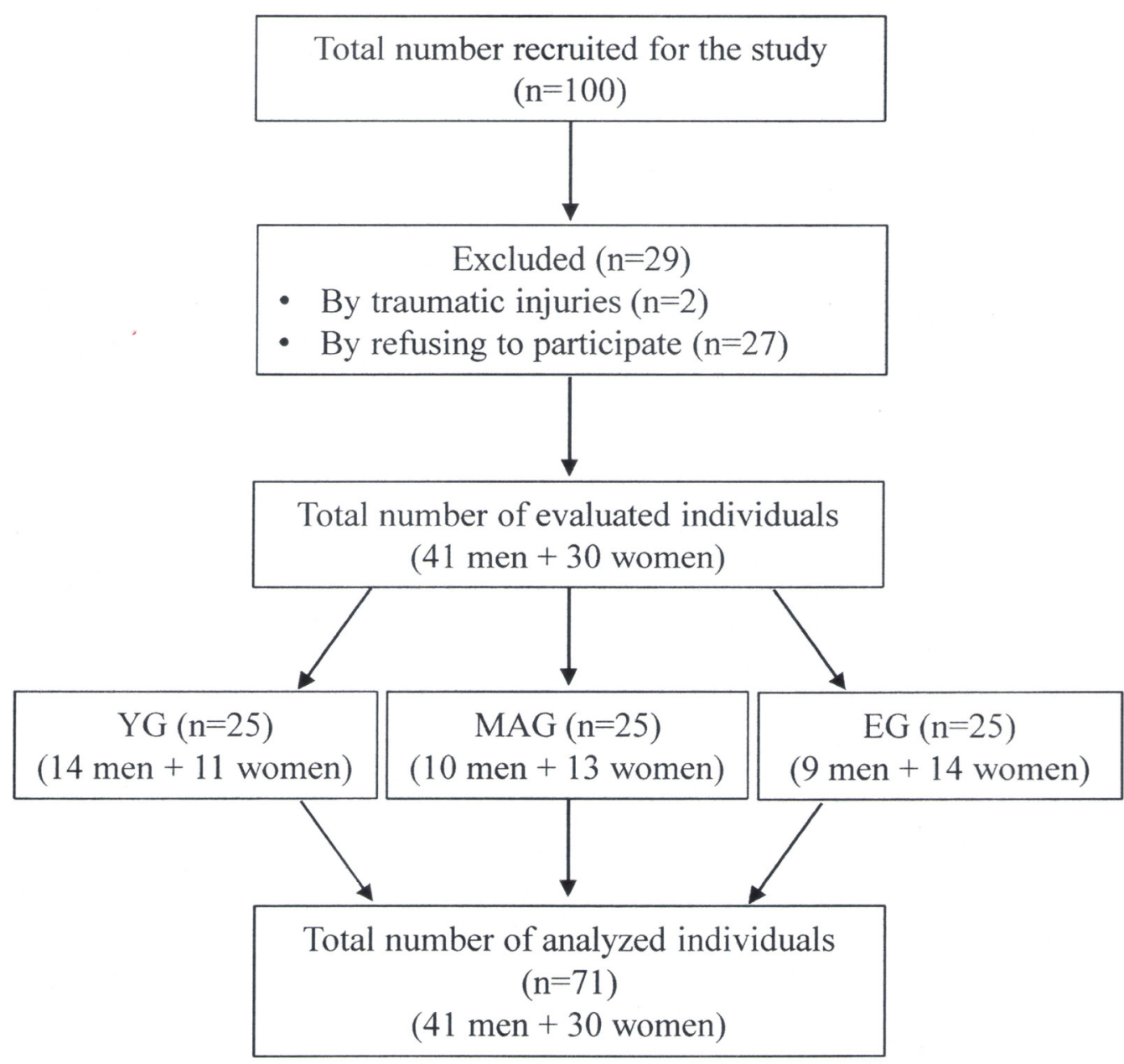

Figure 1. Flow diagram of the sample.

\section{Equipment}

Anthropometric data (weight and height) was collected using analog scale, $100 \mathrm{~g}$ accuracy and coupled with a stadiometer (Filizola, Brazil). Static postural balance was assessed in the anterior-posterior and mediolateral directions using a force platform (EMG System, Brazil), with a sampling frequency of $100 \mathrm{~Hz}$.

\section{Procedures}

Initially, individuals' anthropometric data (age, weight and height) were registered barefoot of each group. During data acquisition via stabilometric (postural oscillation), each individual was asked stand on a force platform (EMG System, Brazil) wearing their normal shoes, in a comfortable and aligned position (i.e., with the body mass distributed as best as possible - based on the coordinate lines of the platform - arms relaxed at their sides), keeping still and silent, gazing an image located one meter away at eye level). After a verbal command (attention, ready, go), individuals were instructed to remain as still as possible during 30 seconds for data collection.
Data collection included: three support conditions (standing on two-feet, DLS); one-foot stance with the dominant leg, DL, and non-dominant leg, NDL, and three visual conditions: full vision, FV (Figure 2A, B and C); partial vision, wearing swimming goggles with $50 \%$ visibility, PV; and occluded vision, wearing swimming goggles with $0 \%$ visibility, AV (Figure $2 \mathrm{D}, \mathrm{E}$ and F). These conditions were randomly presented (Dalal, 2008).

One minute rest time was given between each condition, and if an individual could not maintain position for 30 seconds on the first try, they were given a second trial and even third trial. Throughout the procedure, a quiet environment was req uired, and a researcher stood beside each individual for their safety. In full vision (FV) condition, some individuals kept their corrective glasses. To prevent possible falls during the assessments of one-foot standing and restricted vision, older individuals wore a parachute vest connected to the ceiling by two metal cables (Figure $2 \mathrm{C}$ and F).

The static postural balance records were analyzed using the 400 BIOMEC software (version 2009 - EMG System, Brazil). Fata was processed using MatLab (Component Runtime 7.6) to quantify the total (TD), anteroposterior (AP; axis Y) and mediolateral (ML; $\mathrm{X}$ axis) displacement of the center of pressure $(\mathrm{CoP})$ (in centimeters), using a second order Butterworth filter. 


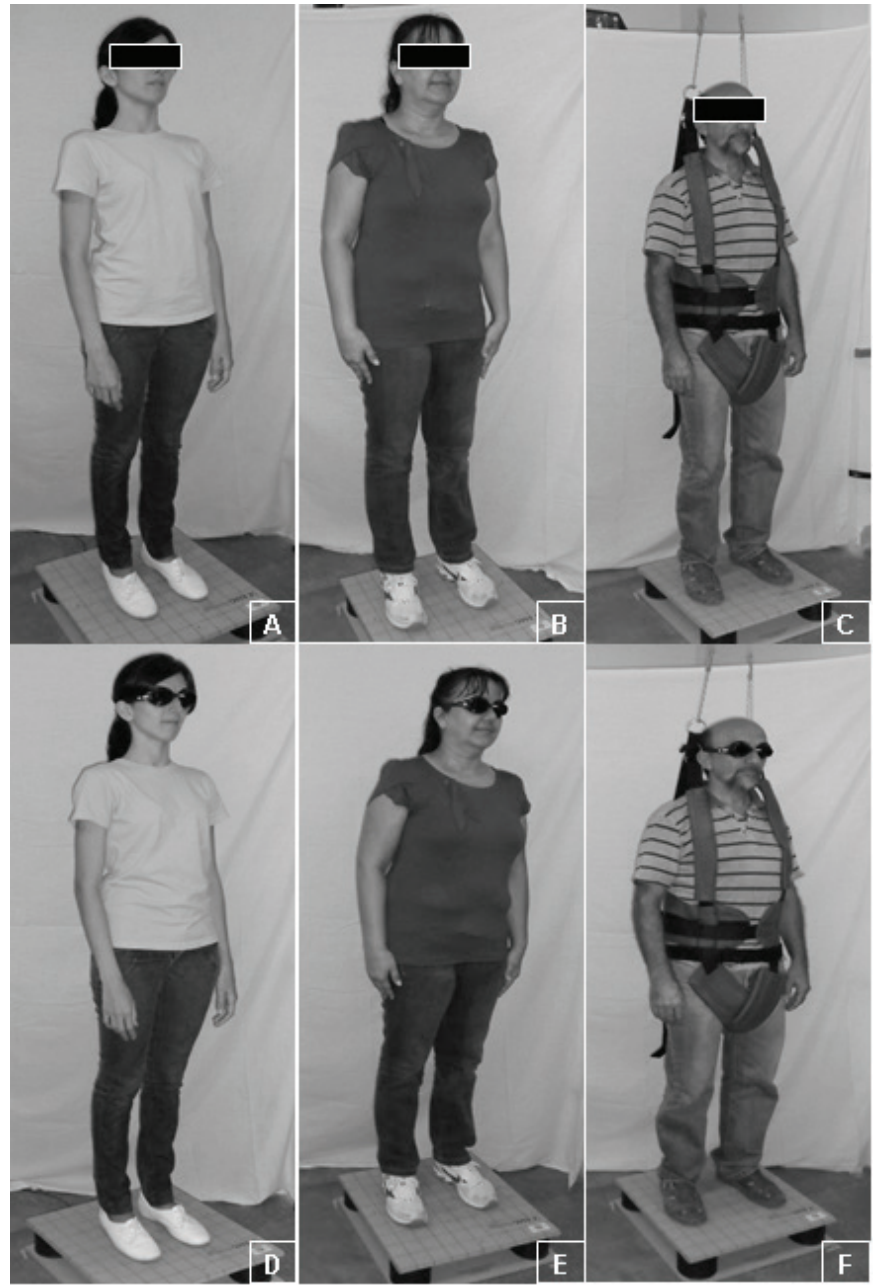

Figure 2. Evaluation of CoP displacement in doble leg-stance (YG, MAG and EG) with full (A, B and C) and partial vision (D, E and F).

\section{Statistical analysis}

The statistical procedures (descriptive and inferential) were performed in Statistical Package for Social Sciences (SPSS 15.0). Normal distribution of the data (Shapiro Wilk's) and homogeneity of variances (Levene's) were confirmed. Then, analysis of variance (ANOVA - three way) was computed for each variable (TD, APD and MLD) considering groups, support and visual conditions. When necessary, Tukey post hoc tests were employed, considering a significance level of $5 \%$.

\section{Results}

The anthropometric characteristics of the groups were: $\mathrm{YG}$ body mass $=64.90 \pm 13.93 \mathrm{~kg}$, height $=1.68 \pm 0.10 \mathrm{~m}$, and $\mathrm{BMI}=$ $22.89 \pm 1.18 \mathrm{~kg} / \mathrm{m}^{2}$; MAG body mass $=69.75 \pm 10.88 \mathrm{~kg}$, height $=1.62 \pm 0.09 \mathrm{~m}, \mathrm{BMI}=26.58 \pm 2.31 \mathrm{~kg} / \mathrm{m}^{2} ;$ EG body mass $=$ $69.58 \pm 11.30 \mathrm{~kg}$, height $=1.57 \pm 0.10 \mathrm{~m}, \mathrm{BMI}=28.23 \pm 2.85 \mathrm{~kg} / \mathrm{m}^{2}$.

The ANOVA three way revealed differences between groups (TD: $F=17.45$; APD: $F=33.21$; MLD: $F=34.70, p<0.01$, respectively), support conditions (TD: $F=137.82$; APD: $F=130.80$; MLD: $F=112.11, p<0.01$, respectively), and visual conditions (TD: $F=8.71$; APD: $F=56.08$; MLD: $F=39.54, p<0.01$, respectively). Interactions between groups and support conditions were detected for the variables TD $(F=3.38, p<0.01)$, APD $(F=4.38$, $p<0.01)$, and MLD $(F=8.11, p<0.01)$ and for groups $\mathrm{X}$ visual conditions for the variables TD $(F=4.72, p<0.01)$, APD $(F=2.49$, $p<0.05)$, and MLD $(F=2.97, p<0.05)$.

According to Table 1, during the one-foot standing task, Tukey post-hoc tests indicated that, regarding the interactions between group and support conditions, the MAG showed higher TD than YG (DL and NDL: $p<0.01$ ) and GE (DL and NDL:

Table 1. Displacement of the center of pressure ( $\mathrm{CoP})$ in the interactions between factors: age groups $\mathrm{X}$ support conditions and age groups $\mathrm{X}$ visual conditions.

\begin{tabular}{|c|c|c|c|c|c|c|c|c|c|}
\hline \multirow{4}{*}{ Variables } & \multicolumn{9}{|c|}{ Factors } \\
\hline & \multicolumn{9}{|c|}{ Age Groups X Support Conditions } \\
\hline & \multicolumn{3}{|c|}{ Young Group (YG) } & \multicolumn{3}{|c|}{ Middle-Aged Group (MAG) } & \multicolumn{3}{|c|}{ Elderly Group (EG) } \\
\hline & DLS & DL & NDL & DLS & DL & NDL & DLS & DL & NDL \\
\hline TD (cm) & $15.2 \pm 7.7$ & $59.1 \pm 51.9^{\mathrm{a}}$ & $59.4 \pm 48.6^{\mathrm{c}}$ & $19.7 \pm 4.4$ & $95.3 \pm 53.4^{\mathrm{a}, \mathrm{b}}$ & $86.0 \pm 47.0^{\mathrm{c}, \mathrm{d}}$ & $19.5 \pm 4.9$ & $69.0 \pm 56.4^{\mathrm{b}}$ & $71.1 \pm 39.5^{\mathrm{d}}$ \\
\hline APD (cm) & $0.7 \pm 0.6$ & $2.0 \pm 1.7^{\mathrm{a}, \mathrm{b}}$ & $1.9 \pm 1.7^{\mathrm{c}, \mathrm{d}}$ & $1.0 \pm 0.4$ & $3.4 \pm 2.3^{\mathrm{a}}$ & $3.1 \pm 1.6^{\mathbf{c}}$ & $1.0 \pm 0.5$ & $3.1 \pm 1.8^{\mathrm{b}}$ & $3.2 \pm 1.8^{\mathrm{d}}$ \\
\hline \multirow[t]{4}{*}{ MLD (cm) } & $0.4 \pm 0.3$ & $1.3 \pm 1.1^{\mathrm{a}, \mathrm{b}}$ & $1.4 \pm 1.2^{\mathrm{d}, \mathrm{e}}$ & $0.5 \pm 0.3$ & $2.6 \pm 2.1^{\mathrm{a}, \mathrm{c}}$ & $2.3 \pm 1.1^{\mathrm{d}, \mathrm{f}}$ & $0.4 \pm 0.2$ & $3.2 \pm 3.2^{\mathrm{b}, \mathrm{c}}$ & $2.8 \pm 2.1^{\mathrm{e}, \mathrm{f}}$ \\
\hline & \multicolumn{9}{|c|}{ Age Groups X Visual Conditions } \\
\hline & \multicolumn{3}{|c|}{ Young Group (YG) } & \multicolumn{3}{|c|}{ Middle-Aged Group (MAG) } & \multicolumn{3}{|c|}{ Elderly Group (EG) } \\
\hline & $\mathbf{A V}$ & PV & FV & AV & PV & FV & AV & PV & FV \\
\hline TD (cm) & $61.9 \pm 61.0$ & $42.2 \pm 40.5^{b}$ & $29.6 \pm 22.7^{\mathrm{d}, \mathrm{e}}$ & $69.5 \pm 63.9^{\mathrm{a}}$ & $76.7 \pm 54.9^{\mathbf{b}, \mathbf{c}}$ & $54.7 \pm 34.3^{\mathrm{d}}$ & $50.4 \pm 59.2^{\mathrm{a}}$ & $56.3 \pm 42.2^{\mathrm{c}}$ & $52.3 \pm 34.7^{\mathrm{e}}$ \\
\hline APD (cm) & $2.09 \pm 2.0^{\mathrm{a}, \mathrm{b}}$ & $1.5 \pm 1.3^{\mathrm{c}, \mathrm{d}}$ & $1.9 \pm 0.9^{\mathrm{e}}$ & $3.5 \pm 2.6^{\mathrm{a}}$ & $2.4 \pm 1.5^{\mathrm{c}}$ & $1.6 \pm 2.6$ & $3.0 \pm 2.2^{\mathrm{b}}$ & $2.5 \pm 1.7^{\mathrm{d}}$ & $1.8 \pm 1.1^{\mathrm{e}}$ \\
\hline MLD (cm) & $.4 \pm 1.4^{\mathrm{a}, \mathrm{b}}$ & $1.0 \pm 1.0^{\mathrm{c}, \mathrm{d}}$ & $0.7 \pm 0.6^{\mathrm{f}}$ & $2.7 \pm 2.4^{\mathrm{a}}$ & $1.6 \pm 1.0^{\mathrm{c}, \mathrm{e}}$ & $1.1 \pm 0.5$ & $2.9 \pm 3.2^{\mathrm{b}}$ & $2.3 \pm 2.5^{\mathrm{d}, \mathrm{e}}$ & $1.3 \pm 1.2^{\mathrm{f}}$ \\
\hline
\end{tabular}

Note: Values are expressed as mean \pm standard deviation. Same letters represent differences between groups (YG, MAG and EG) for each variable (TD, APD and MLD) in each line.

Legend: DLS = doble leg stance, $\mathrm{DL}=$ dominant limb; NDL = non-dominant limb; TD = total displacement; $\mathrm{APD}=$ anteroposterior displacement; $\mathrm{MLD}=$ mediolateral displacement; $\mathrm{cm}$ = centimeter; $\mathrm{AV}=$ absent vision; $\mathrm{PV}=$ partial vision; $\mathrm{FV}=$ full vision. 
$p<0.01$ and $p<0.05$, respectively). The MAG and EG showed higher APD than YG during the one-foot standing task, in both legs (DL and NDL: $p<0.01$ ). MAG and EG showed higher MLD than YG $(p<0.01)$; and EG showed greater MLD than MAG during the one-foot standing task for both legs (DL and NDL: $p<0.05$, respectively).

Regarding the interaction between group and visual conditions, MAG showed higher TD than EG $(p<0.05)$ during the visual occlusion condition; and higher TD that YG $(p<0.01)$ and EG $(p<0.05)$ during partial vision condition. During the full visual condition, MAG $(p<0.01)$ and EG $(p<0.01)$ exhibited higher TD than YG.

With respect to APD, MAG and EG showed higher values than YG during the visual occlusion and partial visual conditions $(p<0.01)$; and EG showed higher values than YG during the full vision condition $(p<0.05)$.

As for the MLD, MAG and EG presented higher averages than YG during visual occlusion $(p<0.01)$ and partial visual conditions ( $p<0.05$ and $p<0.01$, respectively). EG showed higher mean values compared to $\mathrm{MAG}$ during partial visual condition $(p<0.05)$, and also EG had higher mean values compared to $\mathrm{YG}$, during the full visual condition $(p<0.05)$.

\section{Discussion}

The results of the present study showed that age has a strong influence on static postural balance when associated with manipulations of support and visual conditions. In general, larger body oscillations - represented by the anterior-posterior (AP) and mediolateral (ML) directions - were found for the individuals of middle age and the older individuals.

Barbieri, Gissot and Pérennou (2010) reported that the changes related to aging interfere with the ability of individuals internally align their bodies with the vertical direction, therefore, playing an important role in postural decline in healthy elderly. However, in the present study, during the one-foot stance, individuals of the MAG group showed higher TD than individuals of the EG group, and the individuals of the YG group. Possibly, for the individuals of the EG, these differences were the result of effects of practice in regular physical exercises (Lojudice, 2008), therefore, improving postural stability and reducing the risk for falls (Nardone \& Schieppati, 2010; Pimentel \& Scheicher, 2009).

In contrast, analysis of the AP and ML directions showed that MAG and EG exhibit higher displacements during onefoot stance than individuals in the YG group, and EG showed greater displacement than MAG in the ML direction. These results corroborate results by Barbieri et al. (2010) and have great clinical relevance. Older individuals often are unable to move from the two-feet to one-foot stance during walking due to difficulties in controlling the lateral movement of their bodies (Rogers \& Mille, 2003).

Despite the differences in postural control between onefoot stance and two-feet stance, in this study no differences were observed between dominant and non-dominant legs, which corroborates with several other studies conducted with both young and older individuals (Alonso, Brech, Bourquin,
\& Greve 2011; Alonso, Bronzatto Filho, Brech, \& Moscoli, 2008; Tookuni et al., 2005).

When we investigated the role of vision, MAG and EG showed higher TD than YG during FV condition. However, MAG showed greater TD than EG during the AV condition, and greater TD than YG and EG during the PV condition. The efficiency of the visual system is an essential factor for body balance (Freitas Júnior, 2003; Sihvonen, Sipilä, \& Era 2004), and consequently, low visual acuity (Macedo, Pereira, Gomes, Silva, \& Castro, 2008) or absence of vision, even if momentary, generates instability (Costa, Goroso, \& Lopes, 2009), which in this study was more evident for the MAG. This can also be related to differences between the levels of physical condition among the groups.

To Bugnariu and Fung (2007), who compared sensorimotor strategies during regulation of upright balance of the young and older healthy adults, aging affects the interaction of the somatosensory and visual systems affecting the ability of the central nervous system (CNS) to maintain upright stance equilibrium. Therefore, older adults tend to show greater AP and ML CoP displacements when compared to young adults.

Kitabayashi, Demura, Kawabata, Uchiyama and Demura (2011) also found through stabilometry, greater sway in the AP and ML direction of healthy older individuals $(n=342)$ compared to young ones $(\mathrm{n}=380)$.

According to Freitas Júnior and Barela (2006), there is a consensus on the decrease of postural control in the elderly, indicating that they sway more than young adults, during both, eyes open and eyes closed conditions.

Our results corroborate others studies (Brooke-Wavell, Perrett, Howarth, \& Haslam, 2002; Cruz, Oliveira \& Melo, 2010) that analyzed the CoP displacement in the AP and ML directions, and that observed that the visual feedback is an important contribution to replace reduced somatosensory and vestibular sensory input in older individuals, especially during one-foot stance tasks (Deyer \& Ashton-Miller, 1999). In addition, for Soares (2010), the importance of vision increases gradually with the advancing of age, becoming a key factor for the stability of older people. He noted that, for adults with ages 20 to 60 years, the stability decreases $30 \%$ when eyes are closed and reaches $50 \%$ for individuals over 60 years.

The fact that individuals in the EG were practicing regular physical activity may somehow have influenced the results of TD. YG and MAG performed only activities of daily living (ADLs), and most studies with older people in the literature include institutionalized (Medeiros et al., 2012) or community residents (Freitas Júnior, 2003), but not engaged in regular physical activity. Furthermore, the use of the parachute vest safety system by the EG group could have an effect on results by adding information that helped stabilization of the body.

\section{Conclusion}

The results showed that, for all three age groups, static postural balance in healthy individuals decreased over time, and conditions of support and vision can negatively affect groups of older age. 


\section{References}

Abreu, S. S. E. \& Caldas, C. P. (2008). Velocidade de marcha, equilíbrio e idade: Um estudo correlacional entre idosas praticantes e idosas não praticantes de um programa de exercícios terapêuticos. Revista Brasileira de Fisioterapia, 12(4), 324-330. Retrieved from http:// www.scielo.br/pdf/rbfis/v12n4/a12v12n4.pdf.

Aikawa, A. C., Braccialli, L. M. P., \& Padula, R. S. (2006). Efeitos das alterações posturais e de equilíbrio estático nas quedas de idosos institucionalizados. Revista de Ciências Médicas, 15(3), 189-196. Retrieved from http://www.puc-campinas.edu.br/periodicocientifico/

Alfieri, F. M. \& Moraes, M. C. L. (2008). Envelhecimento e o controle postural. Saúde Coletiva, 4(19), 30-33. Retrieved from http:// redalyc.uaemex.mx/pdf/842/84201907.pdf.

Alfieri, F. M., Riberto, M., Gatz, L. S., Ribeiro, C. P. C., Lopes, J. A. F., \& Battistella, L. R. (2012). Comparison of multisensory and strength training for postural control in the elderly. Clinical Interventions in Aging, 7, 119-125. doi: 10.2147/CIA.S27747

Alfieri, F. M., Riberto, M., Gatz, L. S., Ribeiro, C. P. C., Lopes, J. A. F., Santarém, J. M.. \& Battistella, L. R. (2010). Funcional mobility and balance in community-dwelling alderly submitted to multisensory versus strength exercises. Clinical Interventions in Aging, 5, 181-185. doi: 10.2147/CIA.S10223

Alonso, A. C., Brech, G. C., Bourquin, A. M., \& Greve, J. M. D. (2011). The influence of lower-limb dominance on postural balance. São Paulo Medical Journal, 129(6), 410-413. Retrieved from http:// www.scielo.br/pdf/spmj/v129n6/v129n6a07.pdf.

Alonso, A. C., Bronzatto Filho, E., Brech, G. C., \& Moscoli, F. (2008). Estudo comparativo do equilíbrio postural entre atletas de judô e indivíduos sedentários. Brazilian Journal of Biomechanics, 9 (17), 130-137. Retrieved from http://citrus.uspnet.usp.br/biomecan/ojs/ index.php/rbb/article/view/84

Alves, N. B. \& Scheicher, M. E. (2011). Equilíbrio postural e risco para queda em idosos da cidade de Garça, SP. Revista Brasileira de Geriatria e Gerontologia, 14(4), 763-768. Retrieved from http:// revista.unati.uerj.br/pdf/rbgg/v14n4/v14n4a15.pdf

Barbieri, G., Gissot, A. S., \& Pérennou, D. (2010). Ageing of the postural vertical. Age (Dordr), 32(1), 51-60. DOI: 10.1007/ s11357-009-9112-5.

Bruni, B. M.; Granado, F. B., \& Prado, R. A. (2008). Avaliação do equilíbrio postural em idosos praticantes de hidroterapia em grupo. O Mundo da Saúde, 32(1), 56-63. Retrieved from http://www. saocamilo-sp.br/pdf/mundo_saude/58/56a63.pdf.

Brooke-Wavell, K., Perrett, L. K., Howarth, P. A., \& Haslam, R. A. (2002). Influence of the visual environment on the postural stability in healthy older women. Gerontology, 48(5), 293-297. doi:10.1159/000065252.

Bugnariu, N. \& Fung, J. (2007). Aging and selective sensorimotor strategies in the regulation of upright balance. Journal of NeuroEngineering and Rehabilitation, 4(19):1-7. doi:10.1186/1743-0003-4-19.

Costa, R. M. C. L.; Goroso, D. G., \& Lopes, J. A. F. (2009). Estabilidade postural de adultos jovens na privação momentânea da visão. Revista Acta Fisiátrica, 16(1), 19-24. Retrevied from: http://www. actafisiatrica.org.br/default.asp?ed=22.

Cruz, A.; Oliveira, E. M., \& Melo, S. I. L. (2010). Análise biomecânica do equilíbrio do idoso. Acta Ortopédica Brasileira, 18(2), 96-99. Retrieved from http://www.scielo.br/pdf/aob/v18n2/v18n2a07.pdf.

Dalal, G. E. (2012). Citind randomization.com. [última modificação em 16/07/2008] Access: 15/03/2012. Retrieved from http://www. radomization.com.

Deyer, T. W. \& Ashton-Miller, J. A. (1999). Unipedal balance in healthy adults: effect of visual environments yielding decreased lateral velocity feedback. Archives of Physical Medicine Rehabilitation, 80(9), 1072-1077. doi: 0003-9993/99/8009-506253.00/0.

Duarte, M. \& Zatsiorsky, V. M. (2002). Effects of body lean and visual information on the equilibrium maintenance during stance. Experimental Brain Research, 146, 60-69. doi: 10.1007/s00221002-1154-1.

Freitas Jr, P. B. (2003). Características comportamentais do controle postural de jovens, adultos e idosos (Dissertação de Mestrado em Ciências da Motricidade, Universidade Estadual Paulista, Rio Claro). Retrieved from http://www.rc.unesp.br/ib/efisica/lem/pdf/ dissertacao_paulo.pdf

Freitas Jr, P. B. \& Barela, J. A. (2006). Alterações no funcionamento do sistema de controle postural de idosas: Uso da informação visual. Revista Portuguesa de Ciências do Desporto, 6(1), 94-105. doi: 1000000000393421.

Gazzola, J. M., Perracini, M. R., Ganança, M. M., \& Ganança, F. F. (2006). Fatores associados ao equilíbrio funcional em idosos com disfunção vestibular crônica. Revista Brasileira de Otorrinolaringologia, 72(5), 683-690. doi: 110976725705762.

Gil, A. W. O., Oliveira, M. R., Coelho, V. A., Carvalho, C. E., Teixeira, D. C., \& Silva, R. A. (2011). Relationship between force platform and two functional tests for measuring balance in the elderly. Revista Brasileira de Fisioterapia, 15(6), 429-435. doi: 1000000000238497.

Instituto Brasileiro de Geografia e Estatística [IBGE] (2000). Censo demográfico: Brasil. Access: 22/02/2012. Retrieved from http:// www.ibge.gov.br/censo/

Instituto Brasileiro de Geografia e Estatística [IBGE] (2010). Censo demográfico: Brasil. Access: 22/02/2012. Retrieved from http:// www.ibge.gov.br/censo/

Kirkwood, T. B. (2002). Evolution of ageing: Mechanisms of ageing and development, The Biology of Ageing, 123(7), 737-745. doi: 10.1016/S0047-6374(01)00419-5.

Kitabayashi, T., Demura, S-I., Kawabata, H., Uchiyama, M., \& Demura, T. (2011). Comparison of the body-sway characteristics of young adults compared to healthy elderly and elderly with equilibrium disorder. Perceptual and Motor Skills, 113(2), 547-556. doi: 10.2466/10.15.26.PMS.113.5.547-556.

Laboratório de epidemiologia e estatística [Lee]: Tamanho da amostra para pesquisa em ciências da saúde. Acess: 08/10/2012; Available: http://www.lee.dante.br.

Leonardi, M. M. (2009). Impacto do desequilíbrio estático e dinâmico no risco de quedas em indivíduos com ataxia espinocerebelar. Revista de Neurociências, 17(2), 178-182. Retrieved from http:// www.revistaneurociencias.com.br/edicoes/2009/RN\%2017\%20 02/16.pdf.

Lojudice, D. C.; Laprega, M. R., \& Vidal, P. (2008). Equilíbrio e marcha de idosos residentes em instituições asilares do município de Catanduva, SP. Revista Brasileira de Geriatria e Gerontologia, 11(2), 181-189. Retrieved from http://revista.unati.uerj.br/scielo.php?script=sci_arttext\&pid=S1809-98232008000200005\&lng=pt\&nrm=iso\&tlng=pt.

Macedo, B. G., Pereira, L. S. M., Gomes, P. F., Silva, J. P., \& Castro, A. N. V. (2008). Impacto das alterações visuais nas quedas, desempenho funcional, controle postural e no equilíbrio dos idosos: Uma revisão de literatura. Revista Brasileira de Geriatria e Gerontologia, 11(3), 419-432. Retrieved from http://revista.unati.uerj.br/scielo.php?script=sci_arttext\&pi$\mathrm{d}=\mathrm{S} 1809-98232008000300010 \& \operatorname{lng}=\mathrm{pt} \& \mathrm{nrm}=\mathrm{i}$ so\&tlng=pt.

Maciel, A. C. C. \& Guerra, R. O. (2005). Prevalência e fatores associados ao déficit de equilíbrio em idosos. Revista Brasileira de Ciência e Movimento, 13(1), 37-44.

Retrieved from http://portalrevistas.ucb.br/index.php/RBCM/article/ view/610/622. 
Medeiros, P. A., Heinz, C., Filippin, L. I., Vendrusculo, A. P., Virtuoso, J. F., Streit, I. A.. \& Mazo, G. Z. (2012). Estudo correlacional entre parâmetros de avaliação da marcha e equilíbrio em idosas institucionalizadas. Revista ConScientiae Saúde, 11(3), 470-476. doi: $10.5585 /$ ConsSaude.v11n3.3436.

Nardone, A. \& Schieppati, M. (2010). The role of instrumental assessment of balance in clinical decision making. European Journal of Physical and Rehabilitation Medicine, 46(2), 221-237.

Nascimento, L. C. G.; Patrizzi, L. J., \& Oliveira, C. C. E. S. (2012). Efeito de quatro semanas de treinamento proprioceptivo no equilíbrio postural de idosos. Fisioterapia e Movimento, 25(2), 325-331. doi: 10.1590/S0103-51502012000200010.

Pimentel, R. M. \& Scheicher, M. E. (2009). Comparação do risco de queda em idosos sedentários e ativos por meio da escala de equilíbrio de Berg. Fisioterapia e Pesquisa, 16(1), 6-10. Retrived from http://www.revistasusp.sibi.usp.br/pdf/fpusp/v16n1/02.pdf.

Ricci, N. A.; Gazzola, J. M., \& Coimbra, I. B. (2009). Sistemas sensoriais no equilíbrio corporal de idosos. Arquivo Brasileiro de Ciências da Saúde, 34(2), 94-100. Retrieved from http://www. nepas.org.br/abcs/v34n2/34abcs094.pdf.

Rogers, M. W. \& Mille, M-L. (2003). Lateral stability and falls in older people. Exercise and Sport Sciences Reviews, 31(4), 182-187. Retrieved from http://www.laps.univ-mrs.fr/IMG/pdf/Rogers_Mille_ESSR_2003.pdf.

Soares, A. V. (2010). A contribuição visual para o controle postural. Revista de Neurociências, 18(3), 370-379. Retrieved from http:// www.revistaneurociencias.com.br/edicoes/2010/RN1803/415\%20 revisao.pdf.

Sihvonen, S. E., Sipilä, S., \& Era, P. A. (2004). Changes in Postural Balance in Frail Elderly Women during a 4-Week Visual Feedback Training: A Randomized Controlled Trial. Gerontology, 50(2), 87-95. doi: 10.1159/000075559.

Tookuni, K. S., Bollinger Neto, R., Pereira. C. A. M., Souza, D. R., Greve, J. M. A., \& Ayala, A. A. (2005). Análise comparativa do controle postural de indivíduos com e sem lesão do ligamento cruzado anterior do joelho. Acta Ortopédica Brasileira, 13(3), 115-119. Retrieved from http://www.scielo.br/pdf/aob/v13n3/ en 25670.pdf.

\section{Authors' note}

Yanne Salviano Pereira (yannesalviano@hotmail.com) and Jéssica Mascena de Medeiros (jessicamascena@yahoo.com.br) graduated in physiotherapy at the Federal University of Paraíba (UFPB), João Pessoa, Paraíba, Brazil.

José Ângelo Barela, PhD (jose.barela@cruzeirodosul.edu.br), and Ana Maria Forti Barela, PhD (ambarela@gmail.com), are professors of the graduate program in Human Movement Sciences, Cruzeiro do Sul University (Unicsul), São Paulo, Brazil.

César Ferreira Amorim, PhD (cesar@emgsystem.com.br), is a professor in the physiotherapy graduate program, University of the City of São Paulo (Unicid), São Paulo, Brazil.

Catarina de Oliveira Sousa (cat.olivsousa@gmail.com) is a PhD student in physiotherapy at the Federal University of São Carlos (UFSCar), São Carlos, São Paulo, Brazil.
Palloma Rodrigues de Andrade, PhD (pallomandrade@gmail.com), José Jamacy de Almeida Ferreira, PhD (jamacy@gmail.com), and Heleodório Honorato dos Santos, PhD (dorioufpb@gmail.com), are professors from the Physiotherapy Department at the Federal University of Paraíba (UFPB), João Pessoa, Paraíba, Brazil.

\section{Corresponding author:}

Heleodório Honorato dos Santos Av. Mons. Odilon Coutinho, 191/402, Cabo Branco, João Pessoa, PB 58045-120

Phone: (55-83) 8750-7708 / 9613-7900

E-mail: dorioufpb@gmail.com

\section{Acknowledgments}

We thank the participants and collaborators in this research, and $\mathrm{CNPq}$ for financial support (Edital Universal 2008). This study was presented at the $2^{\text {nd }}$ Brazilian Congress of Electromyography and Kinesiology (II Cobec) at Piracicaba, State of São Paulo in 2012.

Manuscript received on February 1, 2013

Manuscript accepted on October 24, 2013 